\title{
Expression of ras Oncogenes in Cultured Human Cells Alters the Transcriptional and Posttranscriptional Regulation of Cytokine Genes
}

\author{
George D. Demetri, ${ }^{\star *}$ Timothy J. Ernst, ${ }^{\star 5}$ Elizabeth S. Pratt II,* Beatrice W. Zenzie," \\ James G. Rheinwald, ${ }^{\dagger \mid}$ and James D. Griffin*s \\ Divisions of Tumor Immunology* and Cell Growth and Regulation ${ }^{\ddagger}$ and Departments of Medicine ${ }^{\S}$ and Cellular and \\ Molecular Physiology" Dana-Farber Cancer Institute and Harvard Medical School, Boston, Massachusetts 02115
}

\begin{abstract}
Autonomous production of cytokines such as the hematopoietic colony-stimulating factors (CSFs), IL-1, or IL-6 has been demonstrated in numerous human and murine neoplasms, and may be involved in the pathogenesis of several paraneoplastic syndromes such as leukocytosis, fever, and hypercalcemia. Because of the high frequency with which mutations in ras protooncogenes have been detected in human tumors, as well as evidence linking ras gene products to activation of certain cellular functions, we investigated whether ras mutations might influence the regulation of cytokine genes. Normal human fibroblasts transfected with a mutant val $^{12} \mathrm{H}$-ras oncogene expressed increased levels of mRNA transcripts encoding granulocyte-CSF (G-CSF), granulocyte-macrophage-CSF (GM-CSF), and IL-1 $\beta$ compared with controls. Human mesothelioma cells transfected with a mutant asp ${ }^{12} \mathrm{~N}$-ras oncogene exhibited similar alterations in cytokine gene expression. Estimates of transcriptional activity by nuclear run-on analysis revealed a selective increase in transcription only for the IL-1 gene. Analysis of mRNA half-life demonstrated a marked increase in the stability of numerous cytokine transcripts, including G-CSF, GM-CSF, IL-1, and IL-6. The addition of anti-IL-1 neutralizing antibody to cultures of cells expressing ras mutants did not block the expression of any of the cytokines examined, suggesting that the baseline expression of GM-CSF, G-CSF, and IL-6 was not a secondary event due to the increased transcription of IL-1. These results indicate that mutations in ras genes may alter expression of several cytokine genes through both transcriptional and posttranscriptional mechanisms. (J. Clin. Invest. 1990. 86:1261-1269.) Key words: colony-stimulating factors $\bullet$ interleukins $\bullet$ mRNA stability $\bullet$ oncogenes
\end{abstract}

\section{Introduction}

The mechanisms that control the production of hematopoietic growth factors (HGFs) ${ }^{1}$ such as granulocyte-macrophage col-

\section{Address correspondence and reprint requests to Dr. George D. Deme- tri, Division of Tumor Immunology, Dana-Farber Cancer Institute, Harvard Medical School, 44 Binney Street, Boston, MA 02115. \\ Received for publication 26 March 1990.}

1. Abbreviations used in this paper: CM, conditioned medium; CSF, colony-stimulating factor; G-CSF, granulocyte-CSF; HGF, hematopoietic growth factor; M-CSF, macrophage-CSF; PKC, protein kinase C; TNF, tumor necrosis factor.

J. Clin. Invest.

(c) The American Society for Clinical Investigation, Inc.

$0021-9738 / 90 / 10 / 1261 / 09 \$ 2.00$

Volume 86, October 1990, 1261-1269 ony-stimulating factor (GM-CSF), granulocyte CSF (G-CSF), macrophage CSF (M-CSF), IL-1, and IL-6 by human cells are complex and poorly understood (1-4). These cytokines can be produced by a wide variety of normal cell types, including $T$ lymphocytes, monocytes, B lymphocytes, fibroblasts, vascular endothelial cells, certain epithelial cells, and mesothelial cells $(1-3,5-14)$. The production of each of these glycoprotein factors may be induced in normal cells by exposure to specific stimuli such as bacterial endotoxin or tumor necrosis factor (TNF) (5-13, 15-19). After stimulation, cytokine production is typically short-lived, even in the continued presence of the inducing stimulus $(7,12)$. In many cell types, multiple cytokine genes are induced simultaneously in response to activating stimuli. For example, treatment of endothelial cells or fibroblasts with TNF rapidly induces concomitant expression of GM-CSF, G-CSF, IL-1, and IL-6 (6, 17-19). However, in other cell types such as $T$ cells, treatment with the same inducing agents stimulates production of only GM-CSF $(2,3$, 20). Similarly, treatment of monocytes with interferon-gamma induces expression of both G-CSF and M-CSF, while treatment with endotoxin selectively induces expression of G-CSF alone $(7,12)$. Thus, different mechanisms exist to allow induction of HGF gene expression in various cell types either in a manner that leads to simultaneous, coordinated production of multiple cytokines or that selectively enhances expression of an individual cytokine.

The regulatory mechanisms that control either coordinated or selective expression of cytokines remain obscure. There is limited evidence that certain coordinate control mechanisms might involve transcriptional control of multiple cytokine genes (21), while posttranscriptional control mechanisms are also believed to be important. For example, the mRNA products of many cytokine genes have AU-rich nucleotide sequences in the $3^{\prime}$-untranslated region that confer instability upon the mRNA transcript $(22,23)$, and cytokine induction after stimulation is associated with increased mRNA half-life $(7,17,22)$.

Aberrant HGF gene regulation has been observed frequently in malignant cells. Abnormal constitutive production of HGFs has been documented in cells derived from carcinomas of the gastrointestinal tract, genitourinary tract, and lung, as well as sarcomas, multiple myelomas, and many types of leukemias (24-32). In many of these neoplasms, constitutive production of several HGFs occurs. For example, the bladder carcinoma cell line 5637 constitutively secretes GMCSF, G-CSF, and IL-1, while normal bladder epithelial cells do not produce HGFs unless stimulated (24). This finding could be explained by postulating that 5637 cells possess multiple mutations involving the regulatory regions of each of these cytokine genes, but it is more likely that a common, trans-acting regulatory mechanism has been perturbed, resulting in coordinate expression of several cytokines. 
During preliminary studies of HGF gene regulation, we found that human fibroblasts which express an H-ras oncogene constitutively produced GM-CSF. Since mutations in the ras family of protooncogenes are frequently observed in the same types of neoplasms that produce HGFs (33-38), we have investigated the effects of introducing ras oncogenes into human cells that do not constitutively produce HGFs. Previous studies have shown that the introduction of a mutant $\mathrm{H}$-ras oncogene alone into normal human cells is generally insufficient to cause malignant transformation (39), but it may alter several cell characteristics. For example, expression of ras mutants in human fibroblasts and mesothelial cells induces morphologic alterations and a decreased requirement for a polypeptide growth factor due to secretion of an autocrine mitogen (40). The studies presented here suggest that expression of mutant ras genes can stimulate mechanisms which result in the coordinate expression of multiple cytokine genes, including GM-CSF, G-CSF, IL-1, and IL-6. Further, the results suggest that a major component of this profound alteration in cytokine gene regulation is mediated through changes in mRNA stability that are normally under the strict control of exogenous signals.

\section{Methods}

Cells and culture conditions. The normal diploid human fibroblast strain R2F, cultured from newborn foreskin, was cultured in M199/ MCDB105 medium supplemented with 7\% fetal calf serum (all purchased from Sigma Chemical Co., St. Louis, MO) as previously described $(14,40,41)$. The human mesothelioma cell line JMN (gift of Dr. A. Behbehani) (42) was cultured in RPMI 1640 medium (Gibco Laboratories, Grand Island, New York) supplemented with $10 \%$ fetal calf serum, $2 \%$ glutamine, and $1 \%$ penicillin/streptomycin. As specified, additions to the culture media in certain experiments included the following: recombinant human tumor necrosis factor (Asahi Chemical Co., New York), recombinant human IL-1 $\alpha$ (gift of Dr. U. Gubler, Roche Research Institute, Nutley, NJ), recombinant human IL-1 $\beta$ (Endogen, Inc., Boston, MA), or polyclonal neutralizing anti-IL-1 antisera (gift of Dr. R. Chizzonite, Roche Research Institute).

Plasmids and transfections. Early passage R2F human fibroblasts expressing ras oncogenes were prepared and described in a previous work (40). In brief, R2F cultures were transfected with plasmid DNA by calcium phosphate-DNA coprecipitation. G418-resistant clones were selected from cotransfections of pSV2neo (43) and the human val $^{12}$ mutant $\mathrm{H}$-ras oncogene $(44,45)$, or by control transfections using pSV2neo alone. Clones expressing the mutant $\mathrm{H}$-ras gene were expanded, and clones 9,13 , and $19(40)$ were examined in this study for cytokine gene expression.

JMN human mesothelioma cells were transfected by electroporation using either pSV2neo alone or a pZIP-derived retroviral vector (46) encoding both neomycin resistance and the human asp ${ }^{12}$ mutant $\mathrm{N}$-ras oncogene. This mutant $\mathrm{N}$-ras oncogene was derived from the human teratocarcinoma cell line PA1 (47). Both plasmids were linearized by a $P v u l$ digestion before transfection. A Cell-porator apparatus (Bethesda Research Laboratories, Bethesda, MD) was used for the electroporations. Stable JMN transfectants were selected in medium containing G418 (Geneticin; Gibco Laboratories), $0.4 \mathrm{mg} / \mathrm{ml}$. G418resistant JMN transfectants were subsequently expanded either as individual clones or as pools of cells.

Expression of the mutant $\mathrm{p} 21^{\text {ras }}$ protein product of the transfected ras oncogenes was confirmed either by immunoblot detection (40) or by immunoprecipitation using the rat anti-p $21^{\text {ras }}$ monoclonal antibody Y13-259 (48) (data not shown). Differentiation of normal p2 $1^{\text {ras }}$ proteins from the mutant versions was based upon differences in electrophorectic mobility of the p $21^{\text {ras }}$ proteins, as previously described (48).

Northern blot analysis. Cells were scraped from preconfluent culture plates, pelleted, lysed in $4 \mathrm{M}$ guanidium isothiocyanate, and layered over $5.7 \mathrm{M}$ cesium chloride. The RNA pellets were recovered after ultracentrifugation at $100,000 \mathrm{~g}$ at $20^{\circ} \mathrm{C}$ for $18 \mathrm{~h}$, resuspended in diethylpyrocarbonate-treated water, and precipitated with ethanol. 10 $\mu \mathrm{g}$ samples of total cellular RNA were run on $1.2 \%$ agarose gels containing 6\% formaldehyde. After electrophoresis, the RNA was blotted to a synthetic nylon transfer membrane (Gene Screen Plus; E. I. DuPont, Wilmington, DE).

Membranes were prehybridized for $1 \mathrm{~h}$ at $65^{\circ} \mathrm{C}$ in a buffer containing $1 \%$ SDS, $1 \mathrm{M} \mathrm{NaCl}$, and $10 \%$ dextran sulfate, then hybridized in the same buffer to which $100 \mu \mathrm{g} / \mathrm{ml}$ salmon sperm DNA and 2.5 $\times 10^{5} \mathrm{cpm} / \mathrm{ml}{ }^{32} \mathrm{P}$-labeled cDNA probe were added. Membranes were washed in $2 \times$ standard saline citrate (SSC) for $10 \mathrm{~min}, 2 \times \mathrm{SSC} / 1 \%$ SDS for $1 \mathrm{~h}$ at $65^{\circ} \mathrm{C}$, and $0.1 \times \mathrm{SSC}$ for $1 \mathrm{~h}$ at room temperature. Autoradiograms were then prepared using intensifying screens.

Plasmids containing cDNAs encoding human M-CSF, G-CSF, GM-CSF, IL-1 $\beta$, IL-3, IL-4, IL-5, and IL-6 were generously supplied by Dr. Steven Clark and Dr. Gordon Wong (Genetics Institute, Cambridge, MA). A plasmid containing the human IL-1 $\alpha$ cDNA was generously provided by Dr. Ueli Gubler (Hoffmann-La Roche, Nutley, NJ). The 4.0-kb M-CSF transcript, the 1.8-kb G-CSF mRNA, the 0.8-kb GM-CSF mRNA, the 1.8-kb IL- $1 \beta$ mRNA, the $2.2-\mathrm{kb}$ IL- $1 \alpha$ mRNA, and the $0.8-\mathrm{kb}$ IL- 6 transcript were detected using radiolabeled cDNA probes. These were labeled with $\left[{ }^{32} \mathrm{P}\right] \mathrm{dCTP}$ to a specific activity of $\sim 10^{9} \mathrm{cpm} / \mu \mathrm{g}$ using the random hexanucleotide primer technique (49). At a later date, blots were rehybridized to a ${ }^{32} \mathrm{P}$-labeled $\beta$-actin cDNA probe as a control for minor variations in RNA sample loading. Actin hybridization patterns correlated well with visualization of the $28 \mathrm{~s}$ and $18 \mathrm{~s}$ ribosomal RNA bands by ethidium bromide staining (data not shown).

Southern blot analysis. Genomic DNA was prepared from preconfluent cultures using the SDS/proteinase $\mathrm{K}$ method with modifications as previously described $(50,51)$. After phenol/chloroform extraction and ethanol precipitation, $15 \mu \mathrm{g}$ of DNA was digested completely with restriction enzymes (New England BioLabs, Beverly, MA). Electrophoresis of the digested DNA was then performed on $1 \%$ agarose gels, and the DNA was blotted to Nitroplus-2000 transfer membranes (Micron Separations, Westborough, MA). Prehybridizations were then performed overnight at $42^{\circ} \mathrm{C}$ in buffer containing $50 \%$ formamide, 0.8 $\mathrm{M} \mathrm{NaCl}, 4 \times$ Denhardt's solution, $0.5 \%$ MOPS, $100 \mu \mathrm{g} / \mathrm{ml}$ salmon sperm DNA, and $0.025 \%$ Sarkosyl. Hybridizations were performed overnight at $42^{\circ} \mathrm{C}$ in the same buffer used for prehybridizations with the addition of $5 \%$ dextran and radiolabeled probe. Probes were labeled as per Northern blot technique and used at a final concentration of 3 $\times 10^{5} \mathrm{cpm} / \mathrm{ml}$. Blots were washed for $30 \mathrm{~min}$ at room temperature in buffer containing $2 \times \mathrm{SET}, 0.1 \%$ sarcosine, $0.05 \% \mathrm{Na}$ pyrophosphate, then washed again for $1 \mathrm{~h}$ at $65^{\circ} \mathrm{C}$ in buffer containing $0.2 \times \mathrm{SET}, 0.1 \%$ sarcosine, $0.05 \% \mathrm{Na}$ pyrophosphate. Autoradiograms were then prepared of the dried blots.

Transcriptional run-on assays. Nascent nuclear RNA transcripts were elongated and radiolabeled as previously described $(52,53)$ with modifications $(7,54)$. In brief, cells were permeabilized in situ with digitonin (Sigma Chemical Co.), washed, scraped, and resuspended on ice at $10^{8} \mathrm{cells} / \mathrm{ml}$. The permeabilized cell suspension was then incubated for $30 \mathrm{~min}$ at $37^{\circ} \mathrm{C}$ in labeling buffer containing $200 \mu \mathrm{Ci}\left[{ }^{32} \mathrm{P}\right]-$ UTP (Amersham Corp., Arlington Heights, IL), $500 \mu \mathrm{M}$ each of ATP, CTP, GTP (Pharmacia Fine Chemicals, Piscataway, NJ), and 20\% glycerol. Cells were then pelletted and resuspended in buffer containing $10 \mathrm{mM}$ Tris, $1 \mathrm{mM}$ EDTA, $100 \mathrm{mM} \mathrm{NaCl}, 10 \mathrm{mM} \mathrm{MgCl}_{2}$, to which was added 15 U DNAse I (Promega Biotec., Madison, WI) and 3 $\mathrm{U}$ of RNAsin (Promega Biotec.), then incubated further $\left(26^{\circ} \mathrm{C}, 15\right.$ $\min )$. The samples were then treated with proteinase $\mathrm{K}, 700 \mu \mathrm{g} / \mathrm{ml}$ final concentration (Bethesda Research Laboratories, Bethesda, MD), in the presence of $0.7 \% \operatorname{SDS}\left(37^{\circ} \mathrm{C}, 30 \mathrm{~min}\right)$. After extraction with 
phenol and chloroform, the radiolabeled RNA was ethanol precipitated twice.

Plasmid DNA (containing both the plasmid sequence and the cDNA coding inserts) was denatured by heat and alkalinization. Denatured plasmids ( $5 \mu \mathrm{g}$ each) were bound to Nitroplus-2000 membranes (Micron Separations, Westborough, MA) using a slot-blot apparatus (Schleicher and Schuell, Keene, NH). After prehybridization of the membranes $\left(65^{\circ} \mathrm{C}\right.$, overnight), labeled elongated RNA species (minimum of $5 \times 10^{5} \mathrm{cpm} / \mathrm{ml}$ ) were hybridized to the membrane-bound denatured plasmid DNAs in hybridization buffer (10 mM TES, 300 $\mathrm{mM} \mathrm{NaCl}, 10 \mathrm{mM}$ EDTA, $0.02 \% \mathrm{SDS}$ ) at $65^{\circ} \mathrm{C}$ for a minimum of 36 h. The membranes were then washed with $0.2 \times$ SSC, $0.1 \%$ SDS at $65^{\circ} \mathrm{C}$ for $1 \mathrm{~h}$, treated with RNase A (Sigma Chemical Co.) $(10 \mu \mathrm{g} / \mathrm{ml}$ in $2 \times \mathrm{SSC}$ for $30 \mathrm{~min}$ at $37^{\circ} \mathrm{C}$ ), and washed again to a final stringency of $0.2 \times \mathrm{SSC}, 0.1 \% \mathrm{SDS}$ at $25^{\circ} \mathrm{C}$ for $1 \mathrm{~h}$. Autoradiograms were then prepared using the dried membranes.

$m R N A$ half-life analysis. Actinomycin D (Sigma Chemical Co.) was added to cultures to a final concentration of $5 \mu \mathrm{g} / \mathrm{ml}$. Using a $\left[{ }^{3} \mathrm{H}\right]$ uridine incorporation assay, this concentration of actinomycin $D$ was shown to abolish completely new RNA synthesis in both the parental cells and the stable transfectants used in these experiments (data not shown). After addition of actinomycin D to cultures, cells were collected at the times noted, cooled on ice, and utilized immediately for RNA preparation.

Densitometric analysis of autoradiograms. Autoradiograms were scanned with an Ultroscan XL laser densitometer (LKB Produkter, Uppsala, Sweden). Comparisons between samples, as noted in the text, were made after normalization to $\beta$-actin mRNA levels for Northern blots. In the case of transcriptional run-on assays, quantitative comparisons were made following normalization to signals from either $\beta$-actin or human repetitive Alu sequences (from the plasmid BLUR 8 [55]).

Bioassays for CSA. Cell-free media from subconfluent cultures were collected, filtered, and assayed for CSF activity. Purified human bone marrow mononuclear cells from a normal volunteer were used as indicator cells for CSF activity. Conditioned medium (CM) from the 5637 bladder carcinoma cell line (obtained from ATCC, Rockville, MD), which autonomously produces CSFs, was used as a positive control. Bone marrow mononuclear cells were cultured at $5 \times 10^{4}$ cells $/ \mathrm{ml}$ in the overlayer of a double-agar assay system for CFU-GM. The overlayer contained $0.3 \%$ agar and $20 \%$ fetal bovine serum in Iscove's modified Dulbecco's minimal essential medium. The CM to be tested was incorporated in a $0.5 \%$ agar underlayer in Iscove's modified Dulbecco's minimal essential medium so that the final concentration of CM in the culture was $10 \%$. CFU-GM were stained and counted on day 14

\section{Results}

The ability of normal human dermal fibroblasts to express selected cytokine genes in vitro after exposure to known inducing stimuli was first evaluated. TNF or bacterial endotoxin induce normal fibroblasts (strain R2F) to express genes for IL-1 $\beta$, G-CSF, and GM-CSF (Fig. 1; data not shown). The kinetics of this induction are similar to endotoxin induction of CSF gene expression in human blood monocytes (7) or mouse peritoneal macrophages (5). G-CSF and/or GM-CSF transcripts accumulate to peak levels by 2 to $10 \mathrm{~h}$ after exposure to the inducing agent, followed by a decline in transcripts to baseline levels within 18 to $36 \mathrm{~h}$, despite continued exposure to the inducer. In contrast, introduction of a mutant val ${ }^{12} \mathrm{H}$-ras oncogene into R2F fibroblasts (40) was found to induce constitutive expression of several cytokine genes, including G-CSF, GM-CSF, and IL-1 $\beta$ in three independent subclones (Fig. 1). M-CSF mRNA was expressed by the parental fibroblasts, and its expression was not altered in the cells expressing the mutant

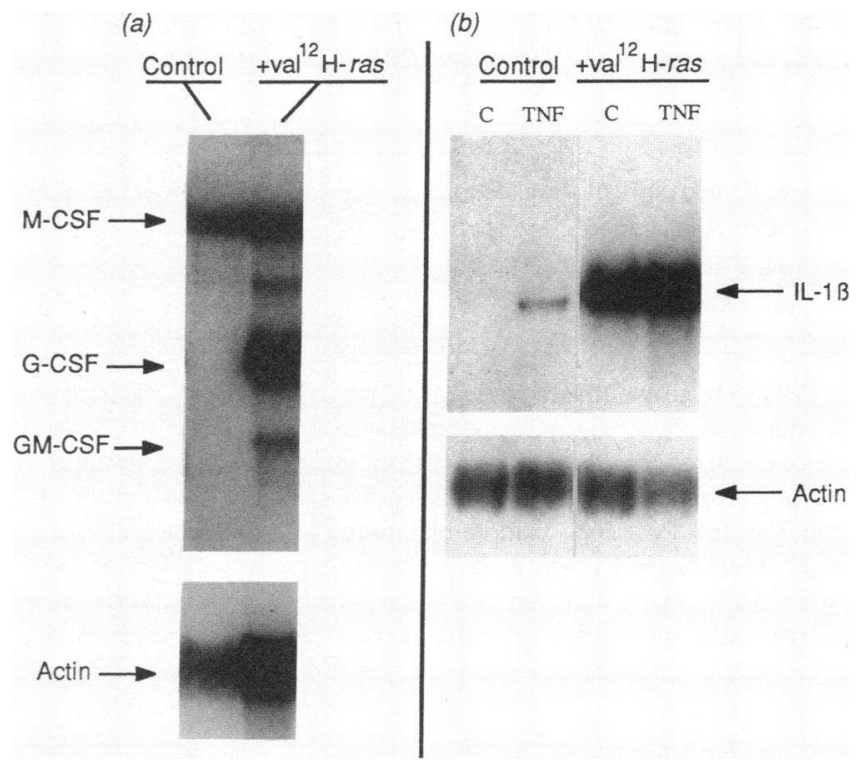

Figure 1. Northern blot analysis of mRNA expression of several cytokine genes in control and ras-transfected human fibroblasts, strain R2F. (a) Baseline expression of CSF transcripts in control R2F fibroblasts and a stable clone of R2F cells which express the mutant val ${ }^{12}$ $\mathrm{H}$-ras oncogene. While there was some variability in the levels of G-CSF and GM-CSF transcripts noted between different clones of stable ras-transfectants, these patterns were reproduced in at least four separate experiments. The unmarked band at $\sim 3.3 \mathrm{~kb}$ (between the M-CSF and G-CSF bands) has been previously observed in blots hybridized to this CDNA probe for GM-CSF (26), and its significance remains unknown. (b) Baseline and TNF-induced expression of IL- $1 \beta$ transcripts in control R2F fibroblasts and a stable clone of $\mathrm{R} 2 \mathrm{~F}$ cells expressing the mutant $\mathrm{val}^{12} \mathrm{H}$-ras oncogene. $C$, control culture conditions; $T N F$, cells exposed to TNF, $100 \mathrm{U} / \mathrm{ml} \times 22 \mathrm{~h}$.

These results are representative of three separate clones examined in at least four experiments.

H-ras gene. The pattern of cytokine gene expression in fibroblasts transfected with pSV2neo alone was unchanged from that seen in the parental R2F cells. In contrast to the regulated induction and suppression of CSF genes characteristic of normal cells, exposure to TNF did not further augment the high level autonomous expression of G-CSF and IL- $1 \beta$ transcripts, while GM-CSF expression was minimally increased by TNF (Fig. $1 b$; data not shown).

The secretion of biologically active CSFs by the mutant ras-transfected $\mathrm{R} 2 \mathrm{~F}$ cells was confirmed by a semiquantitative cell proliferation bioassay which would detect both G-CSF and GM-CSF; IL-1 activity was not measured (Table I). Conditioned media from each of the mutant ras-transfected fibroblast clones tested contained higher levels of CSF activity than media from control cells. This is consistent with work in other systems, in which production of biologically active CSFs is associated with increased levels of detectable mRNA transcripts on Northern blots (26).

Further studies of the association between mutant ras expression and alterations in cytokine gene expression were undertaken in a second cell type with a different ras oncogene in order to test the generalizability of the results obtained in the R2F fibroblasts. We have previously characterized the regulation of CSF genes in normal human mesothelial cells and 
Table I. Secretion of Biologically Active Colony-stimulating Factors by Clones of Transfected R2F Fibroblasts

\begin{tabular}{lc}
\hline \multicolumn{1}{c}{ Source of conditioned media } & CFU-GM $/ 5 \times 10^{4}$ cells $^{\ddagger}$ \\
\hline R2F-neo control transfectants & 25 \\
R2F-Ras, clone 9 & 47 \\
R2F-Ras, clone 19 & 67 \\
5637 cell line & 190 \\
\end{tabular}

* Cells were grown to subconfluent concentrations, and cell-free media were collected, filtered, and assayed for CSF activity.

${ }^{\ddagger}$ Bone marrow mononuclear cells from normal volunteers were used as indicator cells for CSF activity as noted in the text. Conditioned medium from the 5637 bladder carcinoma cell line, which constitutively secretes HGFs, was used as a positive control. CFU-GM were stained and counted on day 14 . The results listed represent the mean of triplicate cultures with a standard error of $\leq 20 \%$ for each value.

mesothelioma cell lines (14). The human mesothelioma cell line JMN, was chosen as a model system for several reasons: JMN cells express only M-CSF transcripts under baseline conditions in vitro, but can be stimulated to express high levels of mRNA for other cytokines including G-CSF, GM-CSF, IL-1 $\beta$, and IL-6; and the parental JMN cell line did not possess endogenous codon 12 mutations in the native $\mathrm{p} 21^{\text {ras }}$ protein (40). JMN cells were transfected by electroporation with either pSV2neo alone or a pZIP-derived vector encoding both neomycin resistance and a mutant $\mathrm{N}$-ras oncogene. G418-resistant cells were then selected and expanded as either individual clones or as grouped pools of stable transfectants. Southern analysis of DNA from clonal transfectants revealed a single copy of the neo gene incorporated per clone, while similar analysis of DNA from pools of transfectants yielded a smear pattern rather than a single distinct band, consistent with a series of random insertion sites for the incorporated neo gene in different individual transfected cells (data not shown).

Fig. 2 represents typical results of Northern analysis of cytokine gene expression in parental, neo-only, and N-ras/ neo-transfected JMN cells. No differences were noted between the cytokine gene expression of clonal transfectants versus pooled groups of transfectants (data not shown). Neither the parental JMN cells nor those transfected with pSV2neo expressed levels of mRNA for either IL- $\beta$ or GM-CSF detectable by Northern blotting. In contrast, the N-ras/neo-transfected JMN cells expressed high levels of transcripts for both of these cytokines, as well as for mRNA encoding G-CSF, IL- $1 \alpha$, and IL-6 (Fig. 4; data not shown). Northern analysis of RNA from the parental JMN cells or either transfectant revealed no transcripts for several other cytokines examined, including IL-3, IL-4, IL-5, and TNF.

To estimate transcriptional activity in the JMN cells, nuclear run-on assays were performed. As shown in Fig. 3, baseline transcriptional activity for several cytokine genes was evident in the parental JMN cells and both stable transfectants, despite the lack of detectable transcript levels by Northern analysis in the parental JMN cells and the pSV2neo-only transfectants. This is consistent with previous reports of the importance of posttranscriptional control for cytokine mRNA transcripts and the relatively low sensitivity of Northern analy- sis $(7,17)$. The level of nonspecific background hybridization was higher in both the pSV2neo and the pZIP-N-ras transfectants studied in three separate experiments. This may reflect the fact that the cDNA inserts were not digested out of the plasmids before denaturation and adherence to the hybridization membrane. Transcription of either the $\beta$-actin gene or human Alu repetitive sequences were used as controls for normalization following densitometric quantification of autoradiograms; equivalent results were obtained when either was used for normalization. No changes were noted in the rates of transcription for GM-CSF, G-CSF, M-CSF, or IL-6 between the parental JMN cells, the pSV2neo transfectants, and the pZIP-N-ras transfectants studied. However, there was a $>20$ fold increase in the estimated rate of transcription for IL-1 $\beta$ and a 3-fold increase in the rate of IL- $1 \alpha$ transcription noted in the JMN transfectants expressing the mutant $\mathrm{N}$-ras oncogene compared with the parental cells. JMN cells expressing neo only, showed no increase in the transcription of IL- $1 \beta$ and a minor (twofold) increase in the transcription of IL-1 $\alpha$. Thus, the increased expression of the IL- $1 \beta$ gene in cells expressing a mutant p2 $1^{\text {ras }}$ involved transcriptional activation, at least in part. No such increase in transcription was evident to explain the aberrantly high baseline levels of transcripts for G-CSF, GM-CSF, and IL-6 in the ras transfectants. This suggested that posttranscriptional mechanisms may be important.

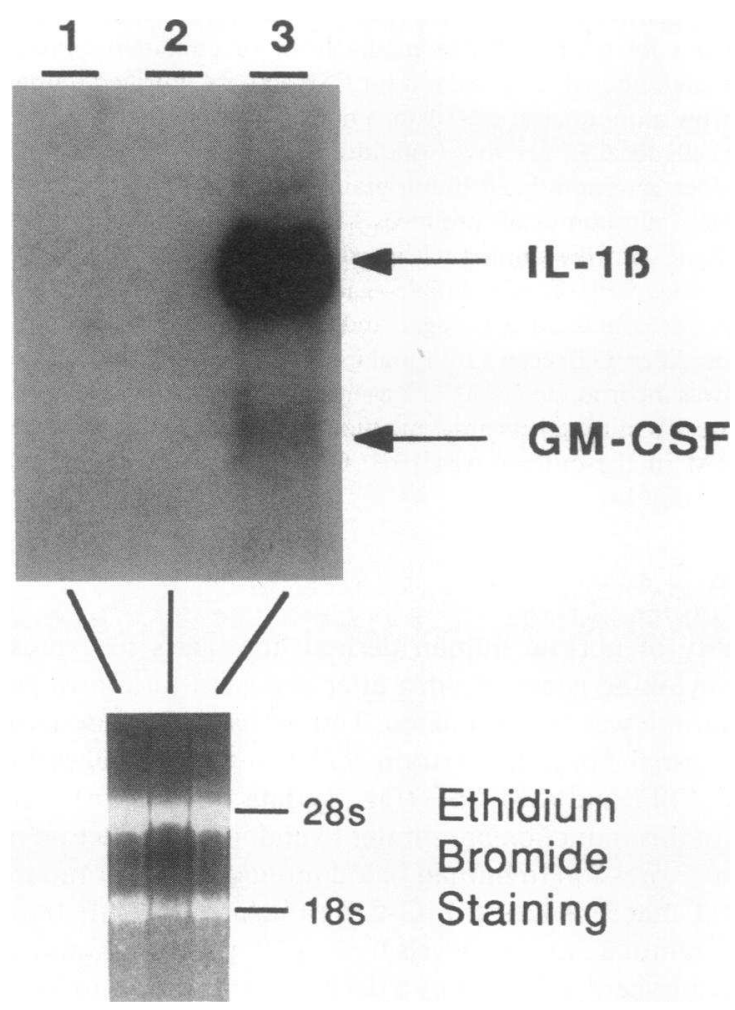

Figure 2. Expression of a mutant asp ${ }^{12} \mathrm{~N}$-ras oncogene in JMN human mesothelioma cells associated with increased expression of the IL- $1 \beta$ and GM-CSF genes. Northern blot of RNA from parental cells (lane 1), pooled cells stably transfected with pSV2neo (lane 2), and pooled cells stably transfected with the pZIP vector encoding the $\mathrm{N}$-ras oncogene, as noted in Methods (lane 3). (Insert) Ethidium bromide staining pattern of gel. 

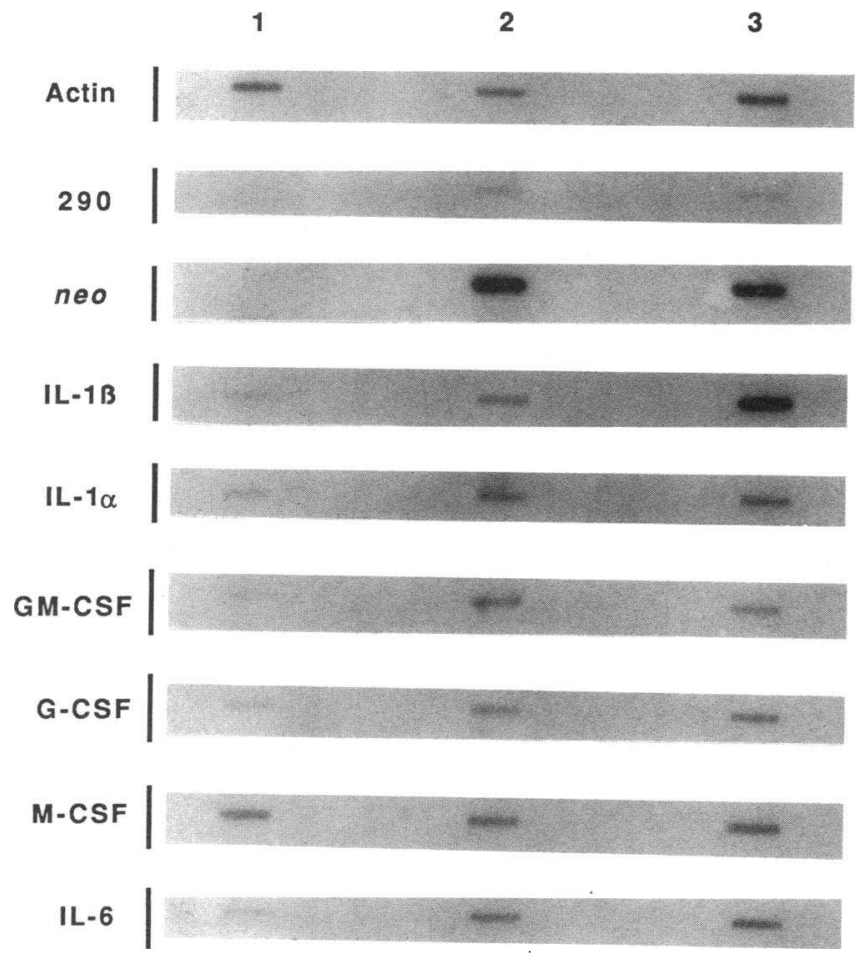

Figure 3. Nuclear run-on assay to estimate rates of transcription of various genes in parental JMN cells (lane 1), pooled JMN cells stably transfected with pSV2neo (lane 2), and pooled JMN cells stably transfected with the mutant asp ${ }^{12} \mathrm{~N}$-ras oncogene (lane 3). Plasmids containing cDNA inserts encoding the human gene sequences listed in the left margin were denatured and slot-blotted onto a support membrane, then radiolabeled RNA from the cells were hybridized to the membranes as listed in Methods. These data are representative of three separate run-on assays. 290 represents a plasmid backbone without any human coding insert; both pSV2neo and ras-transfected cells exhibited increased background signals as evidenced by binding to 290 sequences. The JMN cells expressing the mutant ras oncogene consistently exhibited increased transcription of the IL- $1 \beta$ gene ( $>20$-fold). Minimally increased transcription (twofold) of IL-1 $\alpha$ was also evident in pSV2neo and ras-transfected cells. Densitometric analysis of all remaining signals normalized to either $\beta$-actin or human ALU sequence signals revealed no differences between control or transfected JMN cells.

Possible changes in mRNA stability due to alterations in posttranscriptional processing were examined by estimating transcript half-lives, using actinomycin-D to block new RNA synthesis (Fig. 4). The estimated half-lives were $>10 \mathrm{~h}$ for several cytokine transcripts examined in the ras-transfected JMN cells, including IL-1 $\beta$, GM-CSF, and IL-6. In comparison, half-life analysis of mRNA transcripts from the JMN cells transfected with pSV2neo alone, could be performed only after the cells were stimulated by exposure to phorbol ester, since the uninduced cells showed no detectable transcripts for IL- $1 \beta$, GM-CSF, or IL-6 by Northern blotting (Fig. 4, $b$ and $c$ ). After exposure to PMA, JMN cells expressing neo alone had transcripts for GM-CSF which had an estimated half-life of $2.5 \mathrm{~h}$, consistent with previous reports of the PMA-induced increase in stability of this cytokine transcript $(7,17)$.

Since IL-1 is known to induce expression of GM-CSF and G-CSF in fibroblasts and other cell types $(8-11,59)$, we con- sidered the possibility that the ras oncogenes were specifically inducing IL-1, which then secondarily induced GM-CSF and G-CSF by transducing a signal through activated endogenous IL- 1 receptors. Both IL- $1 \alpha$ and IL- $1 \beta$ were found to induce expression of IL- $1 \beta$, IL- $1 \alpha$, GM-CSF, G-CSF, and IL-6 in JMN cells (data not shown). We therefore attempted to block the action of secreted IL- $1 \beta$ by incubating the ras-transfected JMN cells with a high concentration of polyclonal neutralizing anti-IL-1 antiserum. No changes in the levels of cytokine transcripts in the ras-transfected JMN cells were noted in the presence of anti-IL-1 antisera for time periods up to $48 \mathrm{~h}$ compared to ras-transfected cells incubated without anti-IL-1 antibodies (data not shown). The concentration of antiserum was sufficient to neutralize $>1,000 \mathrm{U} / \mathrm{ml}$ of IL- 1 activity. It is possible, however, that IL-1 produced in an autocrine manner might bind to intracellular IL-1 receptors and not be blocked by anti-IL-1 antibodies.

\section{Discussion}

In this study, we have investigated the effects of mutant ras oncogene expression on a commonly observed phenotypic property of neoplastic cells, aberrant cytokine production. Our results demonstrate that expression of a mutant ras oncogene in at least two different cell types, fibroblasts and mesothelial cells, is associated with significant alterations in the regulation of genes encoding several cytokines, including IL- $1 \alpha$, IL- $1 \beta$, G-CSF, GM-CSF, and IL-6. Further, our data suggest that the mechanism is likely to involve activation of signal transduction pathways which normally regulate expression of numerous cytokine genes, rather than individual mutational events in multiple cytokine genes.

The mechanisms that control production of cytokines by normal human cells are complex (1). Posttranscriptional processing of mRNA transcripts represents a significant control point for gene expression, as does the rate of gene transcription. Nuclear run-on assays have indicated that normal human fibroblasts constitutively transcribe the GM-CSF gene, although GM-CSF mRNA is undetectable by Northern analysis in unstimulated cells $(7,11,17)$. Exposure of fibroblasts to TNF or LPS results in the accumulation of GM-CSF mRNA, mediated by increases in both mRNA stability and the rate of transcription (17). Murine peritoneal macrophages induced by inflammatory mediators accumulate GM-CSF mRNA primarily by posttranscriptional mechanisms (5). Posttranscriptional regulation is also critical for G-CSF and M-CSF production by human monocytes (7).

Our data indicate that the aberrant cytokine gene expression associated with expression of mutant ras oncogenes is the result of alterations in both transcriptional activity (in the case of IL- $1 \beta$ ) and posttranscriptional processing (IL-1 $\beta$, GM-CSF, G-CSF, and IL-6). Examination of individual clones of stable transfectants revealed one copy of the transferred gene per clone with apparently random insertion sites. This suggests that the transcriptional activation of IL- $1 \beta$ was not due simply to insertion of promoter elements near the IL- $1 \beta$ gene. This remains a formal possibility, however, and insertional activation of cytokine genes by retroviruses has previously been reported (60). The small increase in the rate of IL- $1 \alpha$ transcription noted in the ras transfectants is of unclear significance, since a small increase in IL- $1 \alpha$ transcription was also seen in 


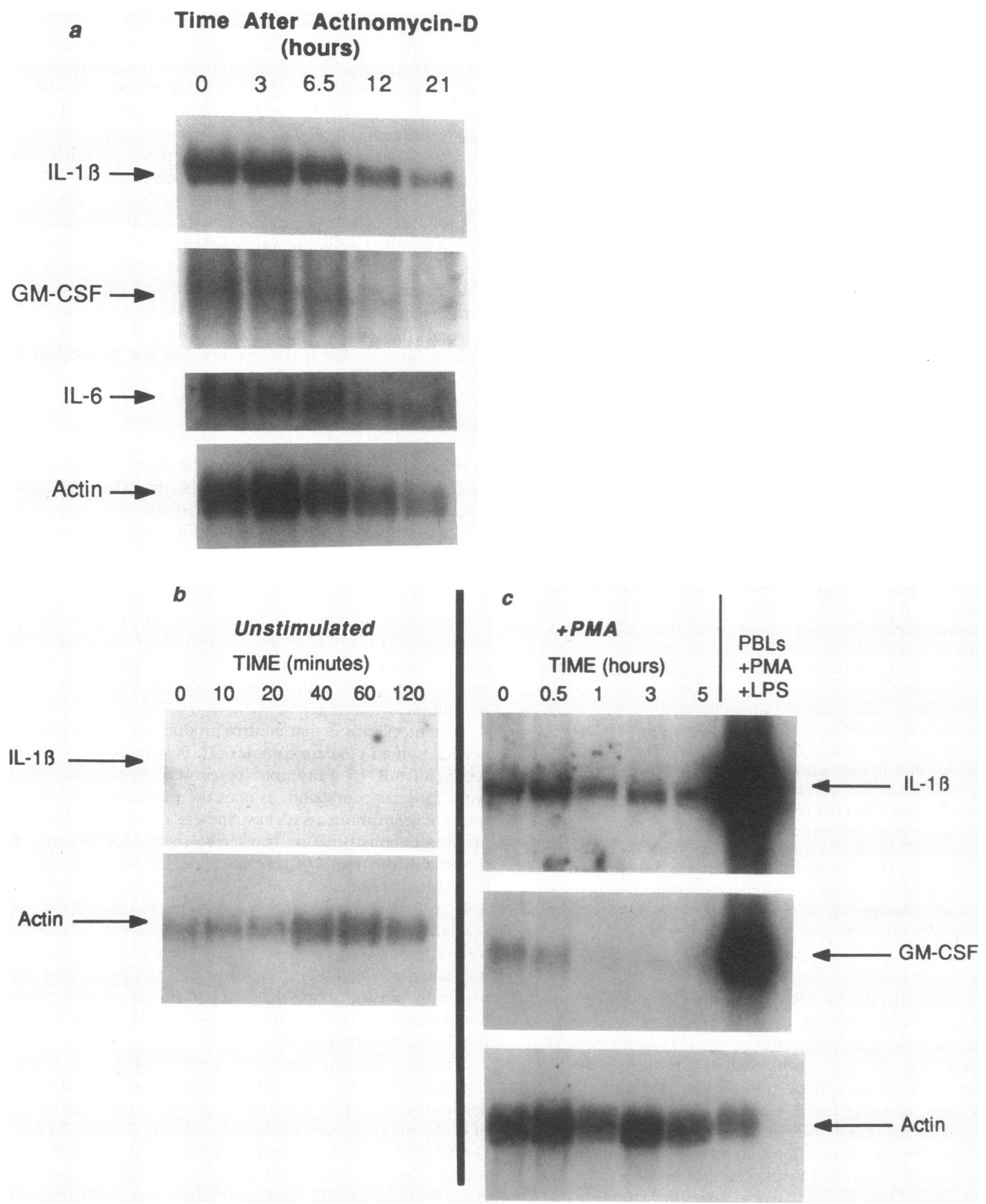

Figure 4. Stability of mRNA encoding several cytokines in transfected JMN cells. (a) Northern blot analysis of RNA derived from JMN cells expressing a mutant asp ${ }^{12}$ ras oncogene. RNA was harvested at the indicated time points after the addition of actinomycin-D, $10 \mu \mathrm{g} / \mathrm{ml}$. These data are representative of at least six different experiments. (b) RNA was prepared from neo-only transfectants under baseline "unstimulated" culture conditions at the time points indicated after the addition of actinomycin-D, $5 \mu \mathrm{g} / \mathrm{ml}$. (c) RNA was prepared from neo-only transfectants exposed to phorbol myristic acetate $(P M A), 10^{-7} \mathrm{M} \times 3 \mathrm{~h}$, at the time points indicated, after the addition of actinomycin-D, $5 \mu \mathrm{g} / \mathrm{ml}$. 
the control neo-only transfectants, which did not exhibit aberrant cytokine gene expression. The increased background hybridization noted in nuclear run-on assays of both the neoonly and ras-transfected cells may be due to binding of plasmid sequences transcribed into cellular RNA to the plasmid DNA attached to the support membrane.

The mechanism by which expression of a mutant $\mathrm{p} 21^{\text {ras }}$ protein induces IL- $1 \beta$ gene transcription is of interest. It has recently been reported that the product of the val ${ }^{12} \mathrm{H}$-ras oncogene stimulates c-fos transcription by activating the fos serum-response element via a pathway independent of both protein kinase $C$ (PKC) and protein kinase A (61). However, other data suggest that ras proteins modulate transcriptional activity through PKC (62). Activation of PKC by phorbol diesters is known to stimulate IL- $1 \beta$ transcription $(1,58)$ and expression of multiple cytokine genes $(1,7,17,22)$. Further studies of the role of PKC in the induction of HGF gene expression associated with ras oncogenes are warranted.

We also observed that the expression of a ras oncogene results in markedly increased stability of the mRNA species encoding IL- $1 \beta$, IL- $1 \alpha$, GM-CSF, G-CSF, and IL-6. Precise measurement of very long mRNA half-lives $(>10 \mathrm{~h})$ is difficult, since prolonged culture with actinomycin $\mathrm{D}$ is toxic. Nevertheless, given the reproducible finding in this study of extremely long mRNA half-lives, we conclude that increased mRNA stability of multiple cytokines is likely to be the major mechanism leading to the observed increase in HGF gene expression.

The coordinate induction of G-CSF, GM-CSF, and IL-1 genes seen in these mutant ras-transfected cells may relate to the fact that the mRNA for these cytokines share a common repeated motif (AUUUA) in the 3'-untranslated ends of the mRNAs which has been shown to confer message instability (22). M-CSF lacks this AUUUA motif in its mRNA, and no changes in M-CSF mRNA levels were noted in the ras-transfectants. One possible explanation of our results is that the expression of mutant ras proteins leads to increased RNA stability of all transcripts with the AUUUA sequences. If so, cells with ras mutations may exhibit increased expression of a variety of other genes that are normally regulated by mechanisms such AU-rich sequences in the 3'-untranslated regions, including other proto-oncogenes and cell cycle control genes (63).

Other mechanisms must exist to increase mRNA stability which do not involve recognition of common AUUUA sequences. For example, the production of both G-CSF and M-CSF by human blood monocytes is regulated by mRNA stability; depending on the stimulus, these genes can be expressed either coordinately or individually (7). Similarly, Schuler and Cole (64) have reported data in a mouse model system that suggests that cells can differentially recognize the AU-rich 3'-untranslated control sequences from different genes, including GM-CSF, c-myc, and c-fos. The cellular mechanisms that result in the increases in mRNA stability of several cytokine genes in ras-transfected human mesenchymal cells require further investigation.

The protein products of the members of the ras gene family, p2 $1^{\text {ras }}$, are structurally related to G-proteins and are thought to play a role in signal transduction (65). It is not possible to determine from the present data whether the codon 12 mutations in the $\mathrm{H}$-ras and $\mathrm{N}$-ras oncogenes used in these studies were required for the effects reported here. In this re- gard, it would be of interest to overexpress a normal c-H-ras protooncogene and evaluate the effects on cytokine gene regulation. In other systems, overexpression of a normal ras protooncogene may produce biological effects similar to the expression of a mutant ras gene product $(61,65)$.

We considered the possibility that our results could be explained by the induction of IL- $1 \beta$ secretion as the primary event. IL-1 has been shown to increase the stability of GMCSF mRNA transcripts (66). We attempted to block secreted IL-1 by adding anti-IL-1 neutralizing antiserum. No differences were observed in the level of cytokine gene expression by ras-transfected cells. However, this does not rule out the possibility that the ras-transfectants may be activated by internal binding of endogenously produced IL-1 to intracellular receptors. For example, it has been shown that the product of the $\mathrm{v}$-sis oncogene can bind and activate intracellular PDGF receptors $(29,67,68)$.

In summary, our data indicate that the expression of mutant ras genes is closely linked to aberrant cytokine gene expression in two different human cell types. Further elucidation of the mechanism by which ras mutations result in dysregulation of cytokine gene expression will lead to a better understanding of the biologic effects of these genetic alterations in cancer cells.

\section{Acknowledgments}

We thank Dr. R. Chizzonite and Dr. U. Gubler of The Roche Institute for their generous gifts of anti-IL-1 antisera and recombinant IL- $1 \alpha$, respectively, and the Asahi Chemical Co. for their generous gift of recombinant human TNF.

Dr. Demetri is a recipient of the Bristol-Myers Oncology Research Grant. Dr. Ernst is a Special Fellow and Dr. Griffin is a Scholar of the Leukemia Society of America. Dr. Rheinwald is a recipient of an American Cancer Society Faculty Research Award. This work was also funded in part by grants CA-34183, CA-36167, CA-47843 (to Dr. Griffin), and CA-26656 (to Dr. Rheinwald) from the National Cancer Institute, National Institutes of Health, Bethesda, MD.

\section{References}

1. Taniguchi, T. 1988. Regulation of cytokine gene expression. Annu. Rev. Immunol. 6:439-464.

2. Clark, S. C., and R. Kamen. 1987. The human hematopoietic colony-stimulating factors. Science (Wash. DC). 236:1229-1237.

3. Cannistra, S. A., and J. D. Griffin. 1988. Regulation of the production and function of granulocytes and monocytes. Semin. Hematol. 25:173-188.

4. Morstyn, G., and A. W. Burgess. 1988. Hemopoietic Growth Factors: a Review. Cancer Res. 48:5624-5637.

5. Thorens, B., J. Mermod, and P. Vassalli. 1987. Phagocytosis and inflammatory stimuli induce GM-CSF mRNA in macrophages through posttranscriptional regulation. Cell. 48:671-679.

6. Le, J., D. Weinstein, U. Gubler, and J. Vilcek. 1987. Induction of membrane-associated interleukin-1 by tumor necrosis factor in human fibroblasts. J. Immunol. 138:2137-2142.

7. Ernst, T. J., A. R. Ritchie, G. D. Demetri, and J. D. Griffin. 1989. Regulation of granulocyte- and monocyte-colony-stimulating factor mRNA levels in human blood monocytes is mediated primarily at a post-transcriptional level. J. Biol. Chem. 264:5700-5703.

8. Warner, S. J.-C., K. R. Auger, and P. Libbey. 1987. Interleukin 1 induces interleukin 1. J. Immunol. 139:1911-1917.

9. Bagby, G. C., C. A. Dinarello, P. Wallace, C. Wagner, S. Hefeneider, and E. McCall. 1986. Interleukin 1 stimulates granulocyte- 
macrophage colony-stimulating activity release by vascular endothelial cells. J. Clin. Invest. 78:1316-1323.

10. Kaushansky, K., N. Lin, and J. W. Adamson. 1988. Interleukin 1 stimulates fibroblasts to synthesize granulocyte-macrophage and granulocyte colony-stimulating factors. J. Clin. Invest. 81:92-97.

11. Yang, Y., S. Tsai, G. G. Wong, and S. C. Clark. 1988. Interleukin-1 regulation of hematopoietic growth factor production by human stromal fibroblasts. J. Cell Physiol. 134:292-296.

12. Vellenga, E., A. Rambaldi, T. J. Ernst, D. Ostapovicz, and J. D. Griffin. 1988. Independent regulation of M-CSF and G-CSF gene expression in human monocytes. Blood. 71:1529-1532.

13. Arend, W. P., D. F. Gordon, W. M. Wood, R. W. Janson, F. G. Joslin, and S. Jameel. 1989. IL-1beta production in cultured human monocytes is regulated at multiple levels. J. Immunol. 143:118-125.

14. Demetri, G. D., B. W. Zenzie, J. G. Rheinwald, and J. D. Griffin. 1989. Expression of colony-stimulating factor genes by normal human mesothelial cells and human malignant mesothelioma cell lines in vitro. Blood. 74:940-946.

15. Munker, R., J. Gasson, M. Ogawa, and H. P. Koeffler. 1986. Recombinant human TNF induces production of granulocyte-monocyte colony-stimulating factor. Nature (Lond.). 323:79-82.

16. Koeffler, H. P., J. Gasson, J. Ranyard, L. Souza, M. Shepard, and R. Munker. 1987. Recombinant human TNF-alpha stimulates production of granulocyte colony-stimulating factor. Blood. 70:55-59.

17. Koeffler, H. P., J. Gasson, and A. Tohler. 1988. Transcriptional and posttranscriptional modulation of myeloid colony-stimulating factor expression by tumor necrosis factor and other agents. Mol. Cell. Biol. 8:3432-3438.

18. Sieff, C. A., C. M. Niemeyer, S. J. Mentzer, and D. V. Faller. 1988. Interleukin-1, Tumor necrosis factor, and the production of colony-stimuläting factors by cultured mesenchymal cells. Blood. 72:1316-1323.

19. Broudy, V. C., K. Kaushansky, G. M. Segal, J. M. Harlan, and J. W. Adamson. 1986. Tumor necrosis type alpha stimulates human endothelial cells to produce granulocyte/macrophage colony-stimulating factor. Proc. Natl. Acad. Sci. USA. 83:7467-7471.

20. Chan, J. Y., D. J. Slamon, S. D. Nimer, D. W. Golde, and J. C. Gasson. 1986. Regulation of expression of human granulocyte/macrophage colony-stimulating factor. Proc. Natl. Acad. Sci. USA. 83:86698673.

21. Stanley, E. R., D. Metcalf, P. Sobieszczuk, N. M. Gough, and A. R. Dunn. 1985. The structure and expression of the murine gene encoding granulocyte-macrophage colony-stimulating factor: evidence for utilisation of alternative promoters. EMBO (Eur. Mol. Biol. Organ.) J. 4:2569-2573.

22. Shaw, G., and R. Kamen. 1986. A conserved AU sequence from the 3'-untranslated region of GM-CSF mediates selective mRNA degradation. Cell. 46:659-667.

23. Caput, D., B. Beutler, K. Hartog, R. Thayer, S. Brown-Shimer, and A. Cerami. 1986. Identification of a common nucleotide sequence in the 3'-untranslated region of mRNA molecules specifying inflammatory mediators. Proc. Natl. Acad. Sci. USA. 83:1670-1674.

24. De Persio, J. F., J. K. Brennan, A. Marshall, A. Lichtman, and B. L. Speiser. 1978. Human cell lines that elaborate colony-stimulating activity for the marrow cells of man and other species. Blood. 51:507519.

25. Coffey, R. J., A. S. Goustin, A. M. Soderquist, G. D. Shipley, J. Wolfshohl, G. Carpenter, and H. L. Moses. 1987. Transforming growth factor $\alpha$ and $\beta$ expression in human colon cancer lines: implications for an autocrine model. Cancer Res. 47:4590-4594.

26. Young, D. C., K. Wagner, and J. D. Griffin. 1987. Constitutive expression of the granulocyte-macrophage colony-stimulating factor gene in acute myeloblastic leukemia. J. Clin. Invest. 79:100-106.

27. Young, D. C., G. D. Demetri, T. J. Ernst, S. A. Cannistra, and J. D. Griffin. 1988. In vitro expression of colony-stimulating factor genes by human acute myeloblastic leukemia cells. Exp. Hematol. 16:378-382.
28. Kawano, M., T. Hirano, T. Matsuda, T. Taga, Y. Horii, K. Iwato, H. Asaoku, B. Tang, O. Tanabe, H. Tanaka, A. Kuramoto, and T. Kishimoto. 1988. Autocrine generation and requirement of BSF/ IL-6 for human multiple myelomas. Nature (Lond.). 332:83-85.

29. Sporn, M. B., and A. B. Roberts. 1985. Autocrine growth factors and cancer. Nature (Lond.). 313:745-747.

30. Sato, K., Y. Fujii, M. Ono, H. Nomura, and K. Shizume. 1987. Production of interleukin 1-alpha-like factor and colony-stimulating factor by a squamous cell carcinoma of the thyroid (T3M-5) derived from a patient with hypercalcemia and leukocytosis. Cancer Res. 47:6474-6480.

31. Wano, Y., T. Hattori, M. Matsuoka, K. Takatsuki, A. O. Chua, U. Gubler, and W. C. Greene. 1987. Interleukin 1 gene expression in adult T cell leukemia. J. Clin. Invest. 80:911-916.

32. Sakai, K., T. Hattori, M. Matsuoka, N. Asou, S. Yamamoto, K. Sagawa, and K. Takatsuki. 1987. Autocrine stimulation of interleukin 1 beta in acute myelogenous leukemia cells. J. Exp. Med. 166:15971602.

33. Needleman, S. W., M. H. Kraus, S. K. Srivastava, P. H. Levine, and S. A. Aaronson. 1986. High frequency of $\mathrm{N}$-ras activation in acute myelogenous leukemia. Blood. 67:753-757.

34. Farr, C. J., R. K. Saiki, H. A. Erlich, F. McCormick, and C. J. Marshall. 1988. Analysis of ras gene mutations in acute myeloid leukemia by polymerase chain reaction and oligonucleotide probes. Proc. Natl. Acad. Sci. USA. 85:1629-1633.

35. Fujita, J., S. K. Srivastava, M. H. Kraus, J. S. Rhim, S. R. Tronick, and S. A. Aaronson. 1985. Frequency of molecular alterations affecting ras protooncogenes in human urinary tract tumors. Proc. Natl. Acad. Sci. USA. 82:3849-3853.

36. Bos, J. L., E. R. Fearon, S. R. Hamilton, M. Verlaan-deVries, J. H. van Boom, A. J. van der Eb, and B. Vogelstein. 1987. Prevalence of ras gene mutations in human colorectal cancers. Nature (Lond.). 327:293-297.

37. Forrester, K., C. Almoguera, K. Han, W. E. Grizzle, and M. Perucho. 1987. Detection of high incidence of K-ras oncogenes during human colon tumorigenesis. Nature (Lond.). 327:298-303.

38. Almoguera, C., D. Shibata, K. Forrester, J. Martin, N. Arnheim, and M. Perucho. 1988. Most human carcinomas of the exocrine pancreas contain mutant c-K-ras genes. Cell. 53:549-554.

39. Sager, R., K. Tanaka, C. C. Lau, Y. Ebina, and A. Anisowicz. 1983. Resistance of human cells to tumorigenesis induced by cloned transforming genes. Proc. Natl. Acad. Sci. USA. 80:7601-7605.

40. Tubo, R. A., and J. G. Rheinwald. 1987. Normal human mesothelial cells and fibroblasts transfected with the EJras oncogene become EGF-independent, but are not malignantly transformed. Oncogene Res. 1:407-421.

41. Connell, N. D., and J. G. Rheinwald. 1983. Regulation of the cytoskeleton in mesothelial cells: reversible loss of keratin and increase in vimentin during rapid growth in culture. Cell. 34:245-253.

42. Behbehani, A. M., W. J. Hunter, A. L. Chapman, and F. Lin. 1982. Studies of a human mesothelioma. Hum. Pathol. 13:862-866.

43. Southern, P. J., and P. Berg. 1982. Transformation of mammalian cells to antibiotic resistance with a bacterial gene under control of the SV40 early region promoter. J. Mol. Appl. Genet. 1:327-341.

44. Tabin, C. J., S. M. Bradley, C. I. Bargmann, R. A. Weinberg, A. G. Papageorge, E. M. Scolnick, R. Dhar, D. R. Lowy, and E. H. Chang. 1982. Mechanism of activation of a human oncogene. Nature (Lond.). 300:143-149.

45. Reddy, E. P., R. K. Reynolds, E. Santos, and M. Barbacid. 1982. A point mutation is responsible for the acquisition of transforming properties by the T24 human bladder carcinoma oncogene. Nature (Lond.). 300:149-152.

46. Jat, P. S., C. L. Cepko, R. C. Mulligan, and P. A. Sharp. 1986. Recombinant retroviruses encoding Simian Virus 40 large $T$ antigen and polyomavirus large and middle $\mathrm{T}$ antigens. Mol. Cell. Biol. 6:1204-1217.

47. Tainsky, M. A., C. S. Cooper, B. C. Giovanella, and G. F. 
Vande Woude. 1984. An activated $r a s^{N}$ gene detected in late but not early passage human PAI teratocarcinoma cells. Science (Wash. DC). 225:643-645.

48. Furth, M. E., T. H. Aldrich, and C. Cordon-Cardo. 1987. Expression of ras proto-oncogene proteins in normal human tissues. Oncogene. 1:47-58.

49. Feinberg, A. P., and B. Vogelstein. 1983. A technique for radiolabelling DNA restriction endonuclease fragments to high specific activity. Anal. Biochem. 132:6-13.

50. Gross-Bellard, M., P. Oudet, and P. Chambon. 1972. Isolation of high molecular weight DNA from mammalian cells. Eur. J. Biochem. 36:32-36.

51. Strauss, W. M. 1987. Preparation of genomic DNA from mammalian tissue. In Current Protocols in Molecular Biology. F. M. Ausbel, R. Brent, and R. E. Kingston, editors. John Wiley \& Sons, New York.

52. Greenberg, M. E., and E. B. Ziff. 1984. Stimulation of 3T3 cells induces transcription of the c-fos proto-oncogene. Nature (Lond.). 311:433-437.

53. Sariban, E., R. Luebbers, and D. Kufe. 1988. Transcriptional and Posttranscriptional control of c-fos gene expression in human monocytes. Mol. Cell Biol. 8:340-346.

54. Ucker, D. S., and K. R. Yamamoto. 1984. Early events in the stimulation of mammary tumor virus RNA synthesis by glucocorticoids: novel assays of transcription rates. J. Biol. Chem. 259:74167420.

55. Rubin, C. M., C. M. Honek, P. L. Deininger, J. Friedman, and C. W. Schmid. 1980. Partial sequence of the 300 nucleotide interdispersed repeated human DNA sequences. Nature (Lond.). 284:372374.

56. Knudsen, P. J., C. A. Dinarello, and T. B. Strom. 1987. Glucocorticoids inhibit transcriptional and post-transcriptional expression of interleukin-1 in U937 cells. J. Immunol. 139:4129-4134.

57. Kern, J. A., R. J. Lamb, J. C. Reed, R. P. Daniele, and P. C. Nowell. 1988. Dexamethasone inhibition of interleukin-1 beta production by human monocytes. Posttranscriptional mechanisms. J. Clin. Invest. 81:237-244.

58. Lee, S. W., A-P. Tsou, H. Chan, J. Thomas, K. Petrie, E. M Eugui, and A. C. Allison. 1988. Glucocorticoids selectively inhibit the transcription of the interleukin- $1 \beta$ gene and decrease the stability of interleukin-1 $\beta$ mRNA. Proc. Natl. Acad. Sci. USA. 85:1204-1208.

59. Van Damme, J., G. Opdenakker, R. J. Simpson, M. R. Rubira, S. Cayphas, A. Vink, A. Billiau, and J. Van Snick. 1987. Identification of the human $26 \mathrm{kd}$ protein, interferon $\beta 2$, as a B-cell hybridoma/plasmacytoma growth factor induced by interleukin 1 and tumor necrosis factor. J. Exp. Med. 165:914-919.

60. Ymer, S., W. Q. J. Tucker, C. J. Sanderson, A. J. Hapel, H. D. Campbell, and I. G. Young. 1985. Constitutive synthesis of interleukin-3 by leukaemia cell line WEHI-3B is due to retroviral insertion near the gene. Nature (Lond.). 317:255-258.

61. Fukumoto, Y., K. Kaibuchi, N. Oku, Y. Hori, and Y. Takai. 1990. Activation of the c-fos serum-response element by the activated c-Ha-ras protein in a manner independent of protein kinase $\mathrm{C}$ and cAMP-dependent protein kinase. J. Biol. Chem. 265:774-780.

62. Imler, J. L., C. Schatz, C. Wasylyk, B. Chatton, and B. Wasylyk. 1988. A Harvey-ras responsive element is also responsive to a tumourpromoter and to serum. Nature (Lond.). 332:275-278.

63. Furukawa, Y., J. A. DeCaprio, A. Freedman, Y. Kanakura, M. Nakamura, T. J. Ernst, D. M. Livingston, and J. D. Griffin. 1990. Expression and state of phosphorylation of the retinoblastoma susceptibility gene product in cycling and non-cycling human hematopoietic cells. Proc. Natl. Acad. Sci. USA. 87:2770-2774.

64. Schuler, G. D., and M. D. Cole. 1988. GM-CSF and oncogene mRNA stabilities are independently regulated in trans in a mouse monocytic tumor. Cell. 55:1115-1122.

65. Barbacid, M. 1987. ras genes. Annu. Rev. Biochem. 56:779827.

66. Bagby, G. C., G. Shaw, M. A. Brown, D. Damm, S. Hefeneider, M. Heinrich, L. Band, and G. M. Segal. 1988. IL-1 induces GM-CSF mRNA accumulation in human stromal cells (HSC) by inducing ribonuclease inhibitory activity. Blood. 72(Suppl):347a (Abstr.)

67. Keating, M. T. and L. T. Williams. 1988. Autocrine stimulation of intracellular PDGF receptors in virus-transformed cells. Science (Wash. DC). 239:914-916.

68. Fleming, T. P., T. Matsui, C. J. Molloy, K. C. Robbins, and S. A. Aaronson. 1989. Autocrine mechanism for v-sis transformation requires cell surface localization of internally activated growth factor receptors. Proc. Natl. Acad. Sci. USA. 86:8063-8067. 